\title{
Konaklama İşletmelerinde Çalışan Personelin Psikolojik Sermayeleri ile Demografik Özellikleri Arasındaki îlişkiler
}

Relationships between Psychological Capital and Demographic Characteristics of Personnel Working in Hospitality Industry

\section{Dr. Halil Özcan ÖZDEMiR ${ }^{1}$}

Başvuru Tarihi: 03.05.2019

Kabul Tarihi: 13.09.2019

Öz

Bu araştırma kapsamında Nevşehir ilindeki 4 ve 5 yıldızlı otel çalışanlarının örgütsel psikolojik sermaye düzeyleri ve çalışanların demografik özelliklerine göre psikolojik sermayelerinin anlamlı bir değişiklik gösterip göstermediği incelenmiştir. Nicel araştırma yöntemlerinden tarama araştırma deseninde yürütülen araştırmada 403 otel çalışanının görüşleri Psikolojik Sermaye Ölçeği ile toplanmıştır. Çalışanların ölçek maddelerine vermiş oldukları cevaplar doğrultusunda öncelikle veri dağılımı incelenmiş ardından betimsel istatistikler, ilişkisiz ölçümlerde t testi ve tek yönlü varyans analizi hesaplanmıştır. Hesaplama sonucunda otel çalışanlarının örgütlerine yönelik iyimserlik, psikolojik dayanıklilık, umut, öz yeterlilik ve psikolojik sermayelerinin yüksek düzeyde olduğu belirlenmiştir. Erkek çalışanların kadın çalışanlara göre öz yeterlilik algılarının daha yüksek olduğu; evli çalışanların bekâr çalışanlara göre psikolojik dayanıklllı, umut, öz yeterlilik ve psikolojik sermaye düzeylerinin daha yüksek olduğu tespit edilmiştir. Çalışanların ögrenim durumlarına, kıdemlerine ve yaşlarına göre psikolojik sermaye düzeylerinde anlamlı bir değişiklik olmadı̆̆ı sonucuna ulaşılmıştır.

Anahtar kelimeler: Psikolojik Sermaye, Demografik Özellikler, Konaklama İşletmeleri

\begin{abstract}
Within the scope of this study, it has been investigated whether the psychological capital levels of 4 and 5-star hotel employees in Nevşehir show a significant change in their psychological capital levels according to their demographic characteristics and organizational psychological capital levels. In the study conducted in the screening research design of quantitative research methods, the remarks of 403 hotel employees were gathered by the Psychological Capital Scale. In accordance with the responses of the employees to the scale items, the data distribution was analyzed firstly, then descriptive statistics, t test and unidirectional variance analysis for unrelated measurements were calculated. As a result of the calculation, it was designated that the employees
\end{abstract}

\footnotetext{
${ }^{1}$ Kırşehir Ahi Evran Üniversitesi Ziraat Fakültesi, hoozdemir@ahievran.edu.tr, ORCID: 0000-0002-0021-3618
} 
of the hotel employees have high levels of optimism, psychological resilience, hope, self-efficacy and psychological capital. It was determined that male employees have higher self-efficacy perceptions than female employees while married workers had higher levels of psychological resilience, hope, self-efficacy and psychological capital than single employees. It was concluded that there is no significant change in psychological capital levels of the employees according to their educational status, seniority and age.

Keywords: Psychological Capital, Demographic Characteristics, Hospitality Industry

\section{Giriş}

İşgörenlerin psikolojik durumlarını iyileştirmek olarak da ifade edilen psikolojik sermaye, işgörenlerin zor görev ve işleri başarabilmek için gerekli çabayı gösterebileceğine güvenip inanma ile de açıklanabilir. Pozitif psikolojik sermaye; örgütsel davranış akımı ile şekillenmiştir ve "özyeterlilik", "iyimserlik", "umut", "dayanıklılı" özellikleri ile açılanabilen psikolojik durum olarak da açıklanabilir (Luthans vd., 2007: 542). Psikolojik sermayenin bileşenlerinden olan öz yeterlilik kavramı işgörenin becerilerinde ne kadar yetkin olduğu ile değil, kendi becerilerine olan inancı ile ilgili bir kavramdır (Özkalp, 2009). İkinci bileşen olan iyimserlikle ilgili çalışma yaşamında kişileri daha çok çalışmaya teşvik edilebilen, zorluklar karşısında dayanıklılık gösteren, fiziksel ve duygusal bakımdan daha canlı olduklarını gösteren araştırma sayısının artmakta olduğu dikkat çekmektedir. Güler'in (2009)'da Seligman ve Schulman'ın (1986) yapmış oldukları çalışmadan aktardığına göre; iş hayatında iyimser bakış açısına sahip olmanın olumlu etkilerine dikkat çekmektedir. Buna göre, iyimser bakış açısına sahip olan satış temsilcilerinin satış miktarlarında ve performanslarında artış olduğunu tespit etmişlerdir. Psikolojik sermayenin üçüncü bileşeni olan umudun zihinsel/fiziksel sağlıkta ve karşlaşılan güçlüklerle mücadele etmede etkili bir özellik olduğunu göstermektedir. İş dünyasında umut; işgörenlerde bir işin başlangıcındaki motivasyonlarını artıran ve yüksek performans sağlayan bir faktördür (Luthans \& Jensen, 2005, 306-307). Son olarak psikolojik sermayenin dayanıklll1k bileşeni; işgörenlerin tüm zorlukları karşlayıp bunlara dayanma güçlerini, esnekliği, uyumu, değişime olan tepkilerini ve süregelen psikolojik baskılar karşısındaki tutumlarını içerir. Dayanıkllık; hayat boyu süren, bireyin çevresi ile arasındaki, sürekli değişim ve belirsizlikler karşısında yaptığı mücadelelerin sonunda kazandığı karmaşık ve hassas bir süreç olarak tanımlanabilir (Özkalp, 2009).

Psikolojik sermaye, psikologlar tarafından bireysel üretkenliğe katkıda bulunan kişisel özellikler olarak tanımlanmaktadır (Gohel, 2012:35). Psikolojik sermaye, kişisel ve örgütsel performansın geliştirilmesi ve yönlendirilmesine yönelik olarak, tecrübeyle veya eğitimle değişebilen ve gelişebilen bir özellikler bütünüdür (Luthans, 2002; Youssef ve Luthans, 2007).

Literatüre baktığımızda konaklama işletmelerindeki psikolojik sermaye ile ilgili çalışmaların bazılarında aşağıdaki sonuçlar elde edilmiştir. 
Kaplan ve Biçkes (2013) Nevşehir ilindeki 5 yıldızlı otel çalışanlarına yaptıkları çalışma sonucuna göre psikolojik sermayenin öz yeterlilik ve umut alt boyutları ile iş tatmini arasında istatistiksel bir ilişki bulamamalarına rağmen dayanıklılık ve iyimserlik alt boyutu ile iş tatmini arasında pozitif yönlü anlamlı bir ilişki tespit etmişlerdir. Karatepe ve Karadaş (2014) otelcilik sektöründe yaptıkları çalışmada yüksek psikolojik sermayeye sahip çalışanların işlerine daha bağlı olduklarını tespit etmişlerdir. Yüksek pozitif sermayeye sahip çalışanların işlerinde, kariyerlerinde ve yaşamlarında daha tatmin olduklarını belirlemişlerdir. Jung ve Yoon (2014) 324 deluxe otel çalışanlarına yaptıkları çalışmada çalışanların pozitif psikolojik sermayelerindeki umut ve iyimserlik etkisinin iş tatminlerini olumlu etkilediği sonucuna varmışlardır.

\section{Psikolojik Sermaye}

Pozitif psikolojik sermaye, birleşik bir üst yapı olarak nitelendirmekte; bireyin psikolojik gelişme hali olarak tanımlanmakta ve "zorlu koşullarda başarılı olmak için gerekli çabayı göstermede kendine güven (öz-yeterlilik), şimdi ve gelecekte başarılı olunacağına dair pozitif yargılar (iyimserlik), başaralı olmak için hedefleri izleme ve gerektiğinde hedefleri gözden geçirip bu hedeflere giden yeni yollar arama (umut), sorunlar ve değişiklikler karşısında, başarıyı elde etmek için dayanıklı olma, yaşanan düşüşlerden sonra eski duruma dönebilme hatta daha ileriye sıçrama- (dayanıklılık)" olarak dört ana unsurdan oluşmaktadır (Luthans, Youssef ve Avolio 2007: 3). Pozitif psikolojik sermaye organizasyonel alanlarda performansı artırmak için bir omurga olarak da kullanılmaktadır. Beşeri sermaye ve sosyal sermaye teorilerinin yanında, pozitif psikolojik sermaye kavramı bireylerin kim olduklarından kim olabileceklerine doğru bir gelişime vurgu yapmaktadır (Luthans, Youssef ve Avolio, 2007: 3).

\section{Psikolojik Sermayenin Boyutları}

Psikolojik sermayenin boyutlarına baktığımızda dört alt boyutunun olduğu görülmektedir.

\section{Umut}

Umut; bir hedefe ulaşmak için yollar tasarlama ve belirlenen bir yolda kararlılık göstermenin bileşkesi olarak ifade edilebilir. Bu bileşenler devamlı şekilde birbirlerini etkileyerek yükseltmektedirler (Snyder, 2000: 10).

\section{Özgüven}

Özgüven bir kişinin bir görevi yerine getirebilme gücüne ilişkin inançlarının toplamı olarak tanımlanmaktadır (Bandura, 1997). Daha geniş bir tanımla özgüven, kişinin motivasyonunu, bilişsel kaynaklarını ve durumsal taleplerle karşılaşmada ihtiyaç duyulan eylemlerini seferber etmedeki yeteneğine duyduğu inancı şeklinde ifade edilebilir (Wood ve Bandura, 1989: 410).

\section{İyimserlik}

İyimserlik psikolojik sermaye unsuru olarak, sadece gelecekte iyi şeylerin olacağını öngörmekle ilgili bir kavram değildir. İyimserlik kavramı, kişinin bazı olayların, pozitif veya negatif; geçmiş, bugün ya da gelecekte neden meydana geldiğini açılamakta kullandığı, nedenler ve atıflara dayanmaktadır. Örneğin, pozitif olaylara odaklanarak oldukça enerji ve zaman harcayabilirsiniz; fakat bunları iyimser açıklayıcı tarzı kullanarak yorumlamıyorsanız, hala kötümser bir bakış açısına sahip olabilirsiniz (Luthans ve diğerleri, 2007: 87).

\section{Dayanıklılık}


Önemli bir güçlük ve risk durumuyla karşılaşıldığında bireylerin bununla başarılı şekilde başa çıkma kabiliyeti dayanıklılık olarak ifade edilebilir. Zamanla değişim gösterebilen dayanıklılık, bireysel ve çevresel koruyucu faktörler tarafından geliştirilmektedir (Stewart ve diğerleri, 1997: 22).

\section{Yöntem}

$\mathrm{Bu}$ bölümde araştırmanın desenine, araştırma grubuna, verilerin toplanmasına ve verilerin çözümlenmesine ilişkin bilgilere yer verilmiştir.

\section{Araştırmanın deseni}

$\mathrm{Bu}$ araştırmanın amacı Nevşehir ilindeki 4 ve 5 yıldızlı otel çalışanlarının örgütsel psikolojik sermaye düzeylerinin belirlenmesi ve çalışanların demografik özelliklerine göre örgütsel psikolojik sermayelerinin anlamlı bir değişiklik gösterip göstermediğinin tespit edilmesidir. $\mathrm{Bu}$ bağlamda araştırma nicel araştırma yöntemlerinden genel tarama modelinde yürütülmüştür. Fraenkel ve Wallen (2009) tarama araştırmalarının asıl amacının bir gruba ait özelliklerin betimlenmesi olduğunu ifade etmektedir. Tarama araştırmaları geçmişte ya da halen var olan bir durumu var olduğu şekliyle betimlemeyi amaçlayan araştırma yaklaşımlarıdır (Karasar, 2008).

Araştırma kapsamında otel çalı̧̧anlarının demografik özellikleri (cinsiyet, medeni durum, öğrenim durumu, kıdem, yaş) araştırmanın $\rightarrow$ bağımsız değişkenleri;

Otel çalışanlarının örgütsel psikolojik sermaye düzeyleri $\rightarrow$ bağımlı değişken, olarak ele alınmıştır.

\section{Evren ve örneklem}

$\mathrm{Bu}$ çalışmanın evrenini Nevşehir'de yer alan yaklaşık 2000 otel çalışanı oluşturmaktadır. Öncelikle evrende yer alan kişileri temsil eden örneklem sayısı belirlenmiş ve Büyüköztürk ve diğerleri (2016) tarafından önerilen Eşitlik 1 kullanılmıştır.

$$
n=\frac{n_{0}}{1+\frac{n_{0}}{N}}
$$

Eşitlik 1. Sürekli değişkenlerde örneklem büyüklüğü tahmini

Eşitlikte yer alan $\mathrm{n}_{0}=\left(\mathrm{t}^{2} \mathrm{PQ}\right) / \mathrm{d}^{2}$ eşitliği ile hesaplanmakta ve $\mathrm{p}$ anlamlılık değeri 0,05 alındığında, $\mathrm{pq}=0,25$ olacağından ve tabloda karşılık gelen $t$ değeri 1,96 olduğundan 0,05 anlamllık düzeyinde $\mathrm{n}_{0}=384,16$ olarak hesaplanmaktadır (Büyüköztürk ve diğerleri, 2016). Evrenden örneklem seçiminde hesaplama aşamasında evren sayısı ve hesaplanan değerler eşitlikte yerine konulmuş ve Eşitlik 2 elde edilmiştir.

$$
\mathrm{n}=\frac{384,16}{1+\frac{384,16}{2000}}
$$

Eşitlik 2. Araştırma kapsamında hesaplanan örneklem büyüklüğü tahmini

Örneklem büyüklüğü tahmininde değerler yerine konulduğunda evreni temsil eden örneklem sayısının en az 322 olduğu belirlenmiştir. Araştırma kapsamında 410 otel çalışanına ulaşılmış veri inceleme sonrasında 403 otel çalışanın görüşleri raporlanmıştır. Başka bir anlatımla araştırma kapsamında ulaşılan örneklem sayısının evrende yer alan otel çalışanlarını niceliksel 
olarak temsil ettiği sonucuna ulaşılmıştır. Örneklemin evreni niteliksel olarak da temsil etmesi amacıyla amaçlı örnekleme yöntemlerinden tabakalı örnekleme yöntemine dayalı olarak seçimler gerçekleştirilmiştir. Tabakalı örnekleme, evreni oluşturan birimlerin incelenecek bu birimlerin özellikleri bakımından farklılık göstermesi durumunda benzer özelliklere sahip birimlerin "tabaka" adı verilen alt gruplarda toplandığı ve örneklemin, her tabakadan ayrı ayrı seçilen örneklemlerin birleştirilmesiyle oluşturulduğu bir örnekleme yöntemidir (Büyüköztürk ve diğerleri, 2016). Araştırma kapsamında il içindeki bölgeler tabaka olarak belirlenmiş ve bu doğrultuda evrendeki ağırlıkları doğrultusunda seçimler gerçekleştirilmiştir.

Araştırmaya katılan otel çalışanlarının demografik özelliklerine göre dağılımlarına yönelik hesaplanan frekans ve yüzde değerleri Tablo 1'de gösterilmiştir.

Tablo 1. Araştırmaya Katılan Otel Çalışanlarının Demografik Özelliklerine Göre Dağılımları

\begin{tabular}{|c|c|c|c|}
\hline Değişkenler & Kategoriler & $\mathbf{f}$ & $\%$ \\
\hline \multirow[t]{2}{*}{ Cinsiyet } & Kadın & 194 & 48,1 \\
\hline & Erkek & 209 & 51,9 \\
\hline \multirow[t]{2}{*}{ Medeni durum } & Evli & 179 & 44,4 \\
\hline & Bekâr & 224 & 55,6 \\
\hline \multirow[t]{4}{*}{ Öğrenim düzeyi } & İlköğretim & 83 & 20,6 \\
\hline & Lise & 139 & 34,5 \\
\hline & Ön lisans & 94 & 23,3 \\
\hline & Lisans ve üstü & 87 & 21,6 \\
\hline \multirow[t]{4}{*}{ Kidem } & 1 yıl ve altı & 61 & 15,1 \\
\hline & $2-4 \mathrm{yll}$ & 142 & 35,2 \\
\hline & 5-9 y1l & 124 & 30,8 \\
\hline & 10 yil ve üstü & 76 & 18,9 \\
\hline \multirow[t]{4}{*}{ Yaş } & $20-24$ & 99 & 24,6 \\
\hline & $25-34$ & 181 & 44,9 \\
\hline & $35-44$ & 81 & 20,1 \\
\hline & 45 ve üstü & 42 & 10,4 \\
\hline
\end{tabular}

Tablo 1'de yer alan bilgiler incelendiğinde araştırma kapsamında görüşleri alınan konaklama sektörü çalışanlarının \%48,1'inin (n=194) kadın, \%51,9'unun $(n=209)$ erkek olduğu görülmektedir. Otel çalışanlarının \%44,4'ü $(n=179)$ evli iken \%55,6'sı (n=224) bekârdır. Otel çalışanlarının öğrenim durumları bazında dağılımları incelendiğinde çalışanların \%20,6'sının ( $n=83)$ ilköğretim, \%34,5’inin ( $n=139)$ lise, \%23,3'ünün ( $n=94)$ ön lisans ve \%21,6'sının ( $n=87)$ lisans ve üstünde eğitime sahip oldukları tespit edilmiştir. Çalışanların \%15,1'inin (n=61) 1 yıl ve altında kıdeme sahip olduğu, \%35,2'sinin ( $n=142)$ 2-4 yıl, \%30,8'inin ( $n=124)$ 5-9 yıl, \%18,9'unun $(\mathrm{n}=76)$ ise kıdemlerinin 10 yıl ve üstünde olduğu belirlenmiştir. Araştırmaya katılan otel çalışanlarının \%24,6'sının ( $n=99$ ) 20-24 yaşında, \%44,9'unun ( $n=181$ ) 25-34 yaşında, \%20,1'inin (n=81) 35-44 yaşında, \%10,4'ünün $(n=42) 45$ yaş ve üstünde olduğu Tablo 1'de görülmektedir. 


\section{Veri Toplama Araçları}

Araştırma kapsamında Nevşehir ilinde görev yapmakta olan otel çalışanlarının örgütlerine yönelik psikolojik sermaye düzeylerinin belirlenmesi ve detaylı incelenmesi amacıyla Luthans vd. (2007) tarafından geliştirilen, Çetin ve Basım (2012) tarafından Türkçeye uyarlaması gerçekleştirilen Psikolojik Sermaye ölçeği kullanılmıştır. Ölçekte dört boyutta toplanan 24 madde bulunmaktadır. Maddelerden üçü $(1,8,11$. maddeler) olumsuz ifade içerdiği için yeniden kodlanmaktadır. Ölçek 5’li Likert tipinde derecelendirilmiş olup ölçeğin tamamından ve iyimserlik, psikolojik dayanıklılık, umut ve öz yeterlilik alt boyutlarından alınan yüksek puanlar çalışanların söz konusu alanların da yüksekliğine işaret etmektedir.

Ölçeğin Türkçeye uyarlama sürecinde Çetin ve Basım (2012) tarafindan öncelikle ölçek maddeleri Türkçeye çevrilmiştir. Çeviri maddelerine yönelik 6 konu alan uzmanı tarafından maddelerin anlaşılırlığı ve kültürel uygunluğu gözden geçirilmiştir. Ardından geri çeviri tekniği kullanılmış ve 2 uzmanın görüşüne dayalı olarak maddelere son hâli verilmiştir. Çevirisi tamamlandıktan sonra ölçek 26 ile 48 yaş aralığında Ankara'da görev yapmakta olan 235 çalışana uygulanmıştır. Uygulama sonrasında elde edilen veriler doğrultusunda öncelikle düzeltilmiş madde-toplam korelasyon katsayıları hesaplanmış, katsayıların 0,030 ile 0,705 arasında değişiklik gösterdiği belirlenmiştir. Ölçeğin iyimserlik boyutu için Cronbach alfa katsayısı 0,67; umut için 0,81; psikolojik dayanıklılık için 0,68 ve öz yeterlilik için ise 0,85 olarak hesaplanmıştır. Ayrıca ölçeğin toplam Cronbach Alfa katsayısı 0,91 olarak hesaplanmıştır. Ölçek maddelerine verilen cevapların güvenirliğinin belirlenmesi amacıyla ayrıca test-tekrar test yöntemine başvurulmuş, katılımcılara ölçek maddeleri 24 gün sonra tekrar uygulanmıştır. Katılımcıların uygulamalardan almış oldukları puanlar arasındaki ilişkiler 0,70 ile 0,77 arasında hesaplanmıştır. Ölçeğin yapı geçerliğinin tespit edilmesi amacıyla doğrulayıcı faktör analizi yapılmış ve analiz sonrasında üç maddenin (1,8 ve 11. maddeler) anlamlı $t$ değerlerine sahip olmadığı belirlenmiş ve ölçekten çıkarılmıştır. Ölçekte kalan 21 maddenin dört faktörlü yapıyı doğruladığı belirlenmiştir. Ölçek maddelerinin standartlaştırılmış faktör yük değerlerinin 0,45 ile 0,73 arasında hesaplandığı tespit edilmiştir. Model-veri uyum değerleri de $\left(\mathrm{X}^{2} / \mathrm{sd}=2,18\right.$; RMSEA=0,057; TLI=0,91 ve CFI=0,90) modelin doğrulandığını göstermiştir. Ölçekten çıkarılan 1,8 ve 11 numaralı maddeler incelendiğinde; 1 ve 11 numaralı maddelerin ölçeğin iyimserlik boyutu içinde olduğu ve 8 numaralı maddenin ise psikolojik dayanıklılık boyutu kapsamında olduğu görülmektedir. Bu maddelerin iyimserlik ve psikolojik dayanıklılık boyutlarına katkı yapmaması; ölçek boyutlarından özellikle umut ile iyimserlik boyutlarının ve öz yeterlilik ile psikolojik dayanıklılık boyutlarının bazı noktalarda benzerlik göstermesi ve kültürel farklılıkların bu süreçte rol oynamasının bir sonucu olarak değerlendirilmiştir (Çetin ve Basim, 2012).

$\mathrm{Bu}$ araştırma kapsamında otel çalışanlarının psikolojik bir kaynak olarak; bireysel seviyede kişisel gelişim ve performansı teşvik eden, örgütsel seviyede insan sermayesi ve sosyal sermayenin bir unsuru olarak performans artısıyla birlikte kaldıraç gücü, yatırım getirisi ve rekabet avantajı yaratan örgütsel psikolojik sermaye yapısını ölçmek için çalışanlara psikolojik sermaye ölçeği uygulanmıştır. Çalışanların ölçek maddelerine vermiş oldukları cevapların güvenirlik düzeyini belirlemek amacıyla Cronbach alfa güvenirlik katsayısı hesaplanmıştır. Hesaplama sonucunda katsayı iyimserlik boyutu için 0,645; umut için 0,657; psikolojik 
dayanıklılık için 0,684 ve öz yeterlilik için ise 0,685 olarak bulunmuştur. Ölçeğin tamamı için Cronbach alfa katsayısı 0,814 olarak hesaplanmıştır. Diğer bir anlatımla araştırmaya katılan çalışanların ölçek maddelerine güvenilir cevaplar verdikleri tespit edilmiştir (Kalayc1, 2009).

\section{Verilerin Analizi}

Araştırma kapsamında Nevşehir'de görev yapmakta olan toplam 410 otel çalışanına ulaşılmıştır. Çalışanların demografik bilgileri ve ölçek maddelerine vermiş oldukları cevaplar SPSS 23.0 programına aktarılmıştır.

Veri aktarımı tamamlandıktan sonra eksik ve hatalı veri girişi olup olmadığı kontrol edilmiştir. Ardından çalışanların maddelere vermiş oldukları cevaplar doğrultusunda toplam puan hesaplanmış ve $\mathrm{z}$ istatistiği hesaplanarak uç değer özelliği gösteren 7 kişi veri setinden çıkarılmıştır. Kalan 403 personelin görüşleri doğrultusunda analizlere devam edilmiştir.

Verilerin çözümlenmesi sürecinde öncelikle veri setinin dağılımı incelenmiş; bu doğrultuda çarpıklık ve basıklık katsayıları hesaplanmıştır. Büyüköztürk (2014) veri setinin büyük olduğu durumlarda normallik varsayımının belirlenmesi için çarpıklık ve basıklık katsayılarının kullanılabileceğini, \pm 1 aralığında yer alan katsayılara ilişkin dağılımların normal dağılıma sahip olduğunu belirtmektedir. Bu doğrultuda psikolojik sermaye ölçeğinin alt boyutlarına ve ölçekten alınan toplam puanlara yönelik çarpıklık ve basıklık katsayıları hesaplanmış ve sonuçlar Tablo 2'de gösterilmiştir.

Tablo 2. Otel Çalışanlarının Psikolojik Sermaye Ölçeği Alt Boyut ve Toplam Puanlarına Yönelik Hesaplanan Çarpıklık ve Basıklık Katsayıları

\begin{tabular}{lccrr}
\hline Ölçek alt boyutları & Çarpıklık & SE & Basıklık & SE \\
\hline İyimserlik & $-0,778$ & 0,122 & 0,411 & 0,243 \\
\hline Psikolojik dayanıklılık & $-0,249$ & 0,122 & $-0,464$ & 0,243 \\
\hline Umut & $-0,581$ & 0,122 & 0,814 & 0,243 \\
\hline Öz yeterlilik & $-0,384$ & 0,122 & $-0,013$ & 0,243 \\
\hline Psikolojik sermaye (toplam) & $-0,380$ & 0,122 & 0,107 & 0,243 \\
\hline
\end{tabular}

Tablo 2'de yer alan bilgiler incelendiğinde otel çalışanlarının psikolojik sermaye ölçeğinden almış oldukları puanların çarpıklık ve basıklık katsayıları \pm 1 arasında değişiklik göstermektedir. Başka bir anlatımla verilerin normal dağılım gösterdiği belirlenmiştir.

Verilerin analizi sürecinde öncelikle hem alt boyutlar bazında hem de toplam puan bazında betimsel istatistikler hesaplanmıştır. Ardından çalışanların cinsiyetine ve medeni durumuna göre psikolojik sermaye düzeylerinin anlamlı bir farklılık gösterip göstermediğinin belirlenmesi amacıyla ilişkisiz ölçümlerde $t$ testi hesaplanmıştır. Çalışanların öğrenim durumlarına, kıdemlerine ve yaşlarına yaşına göre öncelikle puanların varyansların homojen olduğu Levene ile test edilmiş ve karşılaştırma için tek yönlü varyans analizi hesaplanmıştır. Fark testlerinde p anlamlılık değeri 0,05 olarak alınmıştır. Son olarak çalışanların psikolojik sermayeleri ile alt 
boyutları arasındaki ilişkilerin belirlenmesi amacıyla Pearson korelasyon katsayısı hesaplanmıştır. Sonuçlar tablo haline getirilmiş ve yorumlanmıştır.

\section{Bulgular}

\section{Betimsel İstatistikler}

Nevşehir ilindeki 4 ve 5 yıldızlı otellerde görev yapmakta olan çalışanların psikolojik sermaye düzeylerinin belirlenmesi amacıyla çalışanların cevapları doğrultusunda betimsel istatistikler hesaplanmış, sonuçlar Tablo 3'de gösterilmiştir.

\section{Tablo 3. Otel Çalışanlarının Psikolojik Sermaye Düzeylerine Yönelik Hesaplanan Betimsel İstatistikler}

\begin{tabular}{lcccccrr}
\hline Ölçek alt boyutları & $\mathbf{N}$ & Minimum & Maksimum & $\overline{\mathbf{X}}$ & $\mathbf{S} \mathbf{x}$ & $\begin{array}{r}\text { Madde } \\
\text { sayısı }\end{array}$ & $\begin{array}{r}\overline{\mathbf{X}} / \text { Madde } \\
\text { sayısı }\end{array}$ \\
\hline Iyimserlik & 403 & 10,00 & 20,00 & 16,56 & 2,47 & 4 & 4,14 \\
\hline Psikolojik dayanıllılık & 403 & 13,00 & 25,00 & 19,83 & 2,87 & 5 & 3,97 \\
\hline Umut & 403 & 13,00 & 30,00 & 24,23 & 3,28 & 6 & 4,04 \\
\hline Öz yeterlilik & 403 & 14,00 & 30,00 & 23,98 & 3,31 & 6 & 4,00 \\
\hline Psikolojik sermaye & 403 & 60,00 & 105,00 & 84,65 & 9,55 & 21 & 4,03 \\
\hline
\end{tabular}

Tablo 3'de yer alan bilgiler incelendiğinde otel çalışanlarının örgütlerine yönelik iyimserlik düzeylerinin 10,00 ile 20,00 arasında değişiklik gösterdiği, ortalamasının 16,56 $( \pm 2,47)$ olarak hesaplandığı belirlenmiştir. Çalışanların psikolojik dayanaklılık puanlarının 13,00 ile 25,00 arasında farklılaştığ çalışanlarının umut boyutundan almış oldukları puanların 13,00 ile 30,00 arasında değişiklik gösterdiği, ortalamasının 24,23 $( \pm 3,28)$ olarak hesaplandığı belirlenmiştir. Çalışanların öz yeterlilik boyutundan almış oldukları puanların 14,00 ile 30,00 arasında farklılık gösterdiği, ortalamasının 23,98 $( \pm 3,31)$ olarak hesaplandığı tespit edilmiştir. Araştırmaya katılan otel çalışanlarının psikolojik sermaye puanlarının 60,00 ile 105,00 arasında değişiklik gösterdiği, ortalamasının 84,65 $( \pm 9,55)$ olarak hesaplandığı belirlenmiştir.

Tablo 3’de görüldüğü gibi psikolojik sermaye ölçeğinin alt boyutlarındaki madde sayıları birbirinden farklılık göstermektedir. Bu nedenle her bir boyuttan alınan ortalama puan, madde sayısına bölünerek 1-5 ranjında ölçeklenmiştir. Hesaplama sonuçları incelendiğinde otel çalışanlarının psikolojik sermaye düzeylerinin tüm alt boyutlarda ve genel olarak yüksek olduğu görülmektedir. Alt boyutlar içinde sırasıyla çalışanların iyimserlik, umut, öz yeterlilik ve psikolojik dayanıklılık düzeylerinin yüksek olduğu Tablo 3'de görülmektedir. 


\section{Fark İstatistikleri}

Araştırma kapsamında görüşleri alınan çalışanların cinsiyetine göre psikolojik sermaye düzeylerinin anlamlı bir değişiklik gösterip göstermediğinin tespit edilmesi amacıyla ilişkisiz ölçümlerde t testi hesaplanmıştır. Sonuçlar Tablo 4'de gösterilmiştir.

Tablo 4. Otel Çalışanlarının Cinsiyetlerine Göre Psikolojik Sermaye Düzeylerine Yönelik Hesaplanan İlişkisiz Ölçümlerde T Testi Sonuçları

\begin{tabular}{|c|c|c|c|c|c|c|c|}
\hline Ölçek alt boyutları & Cinsiyet & $\mathbf{N}$ & $\overline{\mathbf{X}}$ & SS & sd & $\bar{t}$ & $\mathbf{p}$ \\
\hline \multirow[t]{2}{*}{ İyimserlik } & Kadın & 194 & 16,41 & 2,57 & & & \\
\hline & Erkek & 209 & 16,69 & 2,37 & 401 & 1,124 & 0,262 \\
\hline \multirow[t]{2}{*}{ Psikolojik dayanıklılık } & Kadın & 194 & 19,71 & 2,96 & & & \\
\hline & Erkek & 209 & 19,94 & 2,78 & 401 & 0,809 & 0,419 \\
\hline \multirow[t]{2}{*}{ Umut } & Kadın & 194 & 24,09 & 3,41 & & & \\
\hline & Erkek & 209 & 24,35 & 3,16 & 401 & 0,815 & 0,416 \\
\hline \multirow[t]{2}{*}{ Öz yeterlilik } & Kadın & 194 & 23,59 & 3,41 & & & \\
\hline & Erkek & 209 & 24,34 & 3,19 & 401 & 2,303 & $0,022 *$ \\
\hline \multirow[t]{2}{*}{ Psikolojik sermaye } & Kadın & 194 & 83,80 & 9,99 & & & \\
\hline & Erkek & 209 & 85,43 & 9,08 & 401 & 1,718 & 0,087 \\
\hline
\end{tabular}

Tablo 4'de görüldüğü gibi otel çalışanlarının cinsiyetlerine göre iyimserlik $\left(\mathrm{t}_{(190)}=0,002 ; \mathrm{p}>0,05\right)$, psikolojik dayanıklılık $\left(\mathrm{t}_{(190)}=1,124 ; \mathrm{p}>0,05\right)$, umut $\left(\mathrm{t}_{(190)}=0,809 ; \mathrm{p}>0,05\right)$ ve psikolojik sermaye $\left(\mathrm{t}_{(190)}=0,815 ; \mathrm{p}>0,05\right)$ düzeyleri anlamlı bir farklılık göstermemektedir. Bununla beraber konaklama sektörü çalışanlarının cinsiyetlerine göre öz yeterlilik algılarının anlamlı bir değişiklik gösterdiği tespit edilmiştir $\left(\mathrm{t}_{(190)}=1,718 ; \mathrm{p}<0,05\right)$. Ortalama puanlar incelendiğinde erkek çalışanların $(24,34 \pm 3,19)$ kadın çalışanlara $(23,59 \pm 3,41)$ göre öz yeterlilik algılarının daha yüksek düzeyde olduğu görülmektedir.

Çalışanların medeni durumlarına göre psikolojik sermaye düzeylerinin anlamlı bir değişiklik gösterip göstermediğinin saptanması amacıyla ilişkisiz ölçümlerde t testi hesaplanmış, sonuçlar Tablo 5'de gösterilmiştir. 
Tablo 5. Otel Çalı̧̧anlarının Medeni Durumlarına Göre Psikolojik Sermaye Düzeylerine Yönelik Hesaplanan İlişkisiz Ölçümlerde T Testi Sonuçları

\begin{tabular}{|c|c|c|c|c|c|c|c|}
\hline Ölçek alt boyutları & Medeni durum & $\mathbf{N}$ & $\overline{\mathbf{X}}$ & SS & sd & $\overline{\mathbf{t}}$ & $\bar{p}$ \\
\hline \multirow[t]{2}{*}{ İyimserlik } & Evli & 179 & 16,68 & 2,15 & & & \\
\hline & Bekâr & 224 & 16,46 & 2,70 & 401 & 0,873 & 0,383 \\
\hline \multirow[t]{2}{*}{ Psikolojik dayanıkl111k } & Evli & 179 & 20,15 & 2,71 & & & \\
\hline & Bekâr & 224 & 19,58 & 2,97 & 401 & 2,008 & $0,045^{*}$ \\
\hline \multirow[t]{2}{*}{ Umut } & Evli & 179 & 24,68 & 2,84 & & & \\
\hline & Bekâr & 224 & 23,87 & 3,55 & 401 & 2,480 & $0,014 *$ \\
\hline \multirow[t]{2}{*}{ Öz yeterlilik } & Evli & 179 & 24,37 & 3,34 & & & \\
\hline & Bekâr & 224 & 23,67 & 3,27 & 401 & 2,113 & $0,035^{*}$ \\
\hline \multirow[t]{2}{*}{ Psikolojik sermaye } & Evli & 179 & 85,87 & 8,53 & & & \\
\hline & Bekâr & 224 & 83,67 & 10,20 & 401 & 2,317 & $0,021 *$ \\
\hline
\end{tabular}

${ }^{*} \mathrm{p}<0,05$

Tablo 5'de yer alan bilgiler incelendiğinde araştırmaya katılan çalışanların medeni durumlarına göre iyimserlik düzeyleri anlamlı bir farklılık göstermemektedir $\left(t_{(190)}=0,873 ; p>0,05\right)$.

Bununla beraber otel çalışanlarının psikolojik dayanıklılık $\left(\mathrm{t}_{(190)}=2,008 ; \mathrm{p}<0,05\right)$, umut $\left(t_{(190)}=2,480 ; p<0,05\right)$, öz yeterlilik $\left(t_{(190)}=2,113 ; p<0,05\right)$ ve psikolojik sermaye $\left(t_{(190)}=2,317\right.$; $\mathrm{p}<0,05)$ düzeylerinin medeni durumlarına göre anlamlı bir değişiklik gösterdiği belirlenmiştir. Ortalama puanlar incelendiğinde evli çalışanların bekâr çalışanlara göre psikolojik dayanıklılıklarının, umutlarının, öz yeterliliklerinin ve psikolojik sermaye düzeylerinin anlamlı bir şekilde daha yüksek olduğu tespit edilmiştir.

Araştırmaya katılan çalışanların öğrenim durumlarına göre psikolojik sermaye puanlarının anlamlı bir farklılık gösterip göstermediğinin belirlenmesine yönelik tek yönlü varyans analizi hesaplanmıştır. Sonuçlar Tablo 6'da gösterilmiştir. 
Tablo 6. Otel Çalışanlarının Öğrenim Durumlarına Göre Psikolojik Sermaye Düzeylerine Yönelik Hesaplanan Tek Yönlü Varyans Analizi Sonuçları

\begin{tabular}{|c|c|c|c|c|c|c|c|}
\hline Ölçek alt boyutları & Öğrenim durumu & $\mathbf{N}$ & $\overline{\mathbf{X}}$ & SS & sd & $\mathbf{F}$ & $\bar{p}$ \\
\hline \multirow[t]{4}{*}{ İyimserlik } & İlköğretim & 83 & 16,34 & 2,87 & \multirow{4}{*}{$\begin{array}{r}3 \\
402\end{array}$} & \multirow{4}{*}{2,536} & \multirow{4}{*}{0,056} \\
\hline & Lise & 139 & 16,93 & 1,99 & & & \\
\hline & Ön lisans & 94 & 16,66 & 2,71 & & & \\
\hline & Lisans ve üstü & 87 & 16,06 & 2,40 & & & \\
\hline \multirow[t]{4}{*}{ Psikolojik dayanıklılık } & İlköğretim & 83 & 19,55 & 2,83 & \multirow{4}{*}{$\begin{array}{r}3 \\
402\end{array}$} & \multirow{4}{*}{0,372} & \multirow{4}{*}{0,773} \\
\hline & Lise & 139 & 19,96 & 2,80 & & & \\
\hline & Ön lisans & 94 & 19,89 & 2,93 & & & \\
\hline & Lisans ve üstü & 87 & 19,82 & 2,97 & & & \\
\hline \multirow[t]{4}{*}{ Umut } & İlköğretim & 83 & 24,17 & 3,02 & \multirow{4}{*}{$\begin{array}{r}3 \\
402\end{array}$} & \multirow{4}{*}{0,221} & \multirow{4}{*}{0,882} \\
\hline & Lise & 139 & 24,08 & 3,45 & & & \\
\hline & Ön lisans & 94 & 24,32 & 3,01 & & & \\
\hline & Lisans ve üstü & 87 & 24,41 & 3,55 & & & \\
\hline \multirow[t]{4}{*}{ Öz yeterlilik } & İlköğretim & 83 & 24,11 & 2,47 & \multirow{4}{*}{$\begin{array}{r}3 \\
402\end{array}$} & \multirow{4}{*}{1,036} & \multirow{4}{*}{0,377} \\
\hline & Lise & 139 & 23,71 & 3,55 & & & \\
\hline & Ön lisans & 94 & 24,44 & 3,41 & & & \\
\hline & Lisans ve üstü & 87 & 23,80 & 3,51 & & & \\
\hline \multirow[t]{4}{*}{ Psikolojik sermaye } & İlköğretim & 83 & 84,17 & 8,92 & \multirow{4}{*}{$\begin{array}{r}3 \\
402\end{array}$} & \multirow{4}{*}{0,250} & \multirow{4}{*}{0,861} \\
\hline & Lise & 139 & 84,68 & 9,71 & & & \\
\hline & Ön lisans & 94 & 85,31 & 9,75 & & & \\
\hline & Lisans ve üstü & 87 & 84,33 & 9,78 & & & \\
\hline
\end{tabular}

Tablo 6'da görüldüğü gibi; araştırmaya katılan çalışanların iyimserlik $\left(\mathrm{F}_{(3,402)}=2,536 ; \mathrm{p}>0,05\right)$, psikolojik dayanıklılık $\left(\mathrm{F}_{(3,402)}=0,372 ; \mathrm{p}>0,05\right)$, umut $\left(\mathrm{F}_{(3,402)}=0,221 ; \mathrm{p}>0,05\right)$, öz yeterlilik $\left(\mathrm{F}_{(3,402)}=1,036 ; \quad \mathrm{p}>0,05\right)$ ve psikolojik sermaye $\left(\mathrm{F}_{(3,402)}=0,250 ; \quad \mathrm{p}>0,05\right)$ düzeyleri öğrenim durumlarına göre anlamlı bir farklılık göstermemektedir.

Araştırma kapsamında görüşleri alınan çalışanların kıdemlerine göre psikolojik sermaye düzeylerinin anlamlı bir değişiklik gösterip göstermediğine yönelik tek yönlü varyans analizi hesaplanmış, sonuçlar Tablo7’de gösterilmiştir. 
Tablo 7. Otel Çalışanlarının Kıdemlerine Göre Psikolojik Sermaye Düzeylerine Yönelik Hesaplanan Tek Yönlü Varyans Analizi Sonuçları

\begin{tabular}{|c|c|c|c|c|c|c|c|}
\hline Ölçek alt boyutları & Kıdem & $\overline{\mathbf{N}}$ & $\overline{\mathbf{X}}$ & SS & sd & $\mathbf{F}$ & $\bar{p}$ \\
\hline \multirow[t]{4}{*}{ İyimserlik } & $1 \mathrm{y} 1 \mathrm{l}$ ve alt1 & 61 & 15,97 & 2,61 & \multirow{4}{*}{$\begin{array}{r}3 \\
402\end{array}$} & \multirow{4}{*}{2,003} & \multirow{4}{*}{0,113} \\
\hline & $2-4$ y1l & 142 & 16,87 & 2,38 & & & \\
\hline & $5-9$ y1l & 124 & 16,55 & 2,26 & & & \\
\hline & 10 yıl ve üstü & 76 & 16,45 & 2,76 & & & \\
\hline \multirow[t]{4}{*}{ Psikolojik dayanıklılık } & 1 y1l ve alt1 & 61 & 19,98 & 3,11 & \multirow{4}{*}{$\begin{array}{r}3 \\
402\end{array}$} & \multirow{4}{*}{0,112} & \multirow{4}{*}{0,953} \\
\hline & 2-4 yil & 142 & 19,87 & 2,79 & & & \\
\hline & $5-9$ y1l & 124 & 19,78 & 2,77 & & & \\
\hline & 10 y1l ve üstü & 76 & 19,72 & 3,00 & & & \\
\hline \multirow[t]{4}{*}{ Umut } & $1 \mathrm{y} 1 \mathrm{l}$ ve alt1 & 61 & 23,61 & 3,50 & \multirow{4}{*}{$\begin{array}{r}3 \\
402\end{array}$} & \multirow{4}{*}{1,323} & \multirow{4}{*}{0,266} \\
\hline & $2-4$ y1l & 142 & 24,58 & 2,75 & & & \\
\hline & $5-9$ y1l & 124 & 24,17 & 3,25 & & & \\
\hline & 10 y1l ve üstü & 76 & 24,14 & 3,97 & & & \\
\hline \multirow[t]{4}{*}{ Öz yeterlilik } & $1 \mathrm{y} 1 \mathrm{l}$ ve alt1 & 61 & 23,66 & 3,46 & \multirow{4}{*}{$\begin{array}{r}3 \\
402\end{array}$} & \multirow{4}{*}{1,343} & \multirow{4}{*}{0,260} \\
\hline & 2-4 y1l & 142 & 23,75 & 3,09 & & & \\
\hline & $5-9$ y1l & 124 & 24,47 & 2,92 & & & \\
\hline & 10 y1l ve üstü & 76 & 23,87 & 4,10 & & & \\
\hline \multirow[t]{4}{*}{ Psikolojik sermaye } & $1 \mathrm{y} 1 \mathrm{l}$ ve alt1 & 61 & 83,21 & 10,75 & \multirow{4}{*}{$\begin{array}{r}3 \\
402\end{array}$} & \multirow{4}{*}{0,609} & \multirow{4}{*}{0,609} \\
\hline & 2-4 y1l & 142 & 85,08 & 8,69 & & & \\
\hline & $5-9$ y1l & 124 & 84,97 & 8,99 & & & \\
\hline & 10 y1l ve üstü & 76 & 84,46 & 10,94 & & & \\
\hline
\end{tabular}

Tablo 7'de yer alan bilgiler doğrultusunda otel çalışanlarının kıdemlerine göre iyimserlik $\left(\mathrm{F}_{(3,402)}=2,003 ; \quad \mathrm{p}>0,05\right)$, psikolojik dayanıkllik $\left(\mathrm{F}_{(3,402)}=0,112 ; \mathrm{p}>0,05\right)$, umut $\left(\mathrm{F}_{(3,402)}=1,323\right.$; $\mathrm{p}>0,05)$, öz yeterlilik $\left(\mathrm{F}_{(3,402)}=1,343 ; \quad \mathrm{p}>0,05\right)$ ve psikolojik sermaye $\left(\mathrm{F}_{(3,402)}=0,609 ; \quad \mathrm{p}>0,05\right)$ düzeyleri anlamlı bir değişiklik göstermemektedir.

Araştırmaya katılan çalışanların yaşlarına göre psikolojik sermaye düzeylerinin anlamlı bir farklılık gösterip göstermediğine yönelik tek yönlü varyans analizi testi hesaplanmıştır. Sonuçlar Tablo 8'de gösterilmiştir. 
Tablo 8. Otel Çalışanlarının Yaşlarına Göre Psikolojik Sermaye Düzeylerine Yönelik Hesaplanan Tek Yönlü Varyans Analizi Sonuçları

\begin{tabular}{|c|c|c|c|c|c|c|c|}
\hline Ölçek alt boyutları & Yaş & $\mathbf{N}$ & $\overline{\mathbf{X}}$ & SS & sd & $\mathbf{F}$ & $\bar{p}$ \\
\hline \multirow[t]{4}{*}{ İyimserlik } & $20-24$ & 99 & 16,59 & 2,36 & \multirow{4}{*}{$\begin{array}{r}3 \\
402\end{array}$} & \multirow{4}{*}{0,212} & \multirow{4}{*}{0,888} \\
\hline & $25-34$ & 181 & 16,47 & 2,54 & & & \\
\hline & $35-44$ & 81 & 16,73 & 2,40 & & & \\
\hline & 45 ve üstü & 42 & 16,52 & 2,59 & & & \\
\hline \multirow[t]{4}{*}{ Psikolojik dayanıklılık } & $20-24$ & 99 & 19,77 & 3,24 & \multirow{4}{*}{$\begin{array}{r}3 \\
402\end{array}$} & \multirow{4}{*}{0,832} & \multirow{4}{*}{0,477} \\
\hline & $25-34$ & 181 & 19,66 & 2,82 & & & \\
\hline & $35-44$ & 81 & 20,00 & 2,80 & & & \\
\hline & 45 ve üstü & 42 & 20,38 & 2,20 & & & \\
\hline \multirow[t]{4}{*}{ Umut } & $20-24$ & 99 & 24,09 & 3,00 & \multirow{4}{*}{$\begin{array}{r}3 \\
402\end{array}$} & \multirow{4}{*}{0,080} & \multirow{4}{*}{0,971} \\
\hline & $25-34$ & 181 & 24,27 & 3,05 & & & \\
\hline & $35-44$ & 81 & 24,25 & 3,88 & & & \\
\hline & 45 ve üstü & 42 & 24,33 & 3,67 & & & \\
\hline \multirow[t]{4}{*}{ Öz yeterlilik } & $20-24$ & 99 & 23,79 & 3,40 & \multirow{4}{*}{$\begin{array}{r}3 \\
402\end{array}$} & \multirow{4}{*}{1,657} & \multirow{4}{*}{0,176} \\
\hline & $25-34$ & 181 & 24,32 & 3,10 & & & \\
\hline & $35-44$ & 81 & 23,38 & 3,78 & & & \\
\hline & 45 ve üstü & 42 & 24,12 & 2,96 & & & \\
\hline \multirow[t]{4}{*}{ Psikolojik sermaye } & $20-24$ & 99 & 84,23 & 9,75 & \multirow{4}{*}{$\begin{array}{r}3 \\
402\end{array}$} & \multirow{4}{*}{0,142} & \multirow{4}{*}{0,935} \\
\hline & $25-34$ & 181 & 84,72 & 9,33 & & & \\
\hline & $35-44$ & 81 & 84,62 & 10,29 & & & \\
\hline & 45 ve üstü & 42 & 85,36 & 8,75 & & & \\
\hline
\end{tabular}

${ }^{*} \mathrm{p}<0,05$

Tablo 8'deki bilgiler incelendiğinde konaklama sektörü çalışanlarının yaşlarına göre iyimserlik $\left(\mathrm{F}_{(3,402)}=0,212 ; \quad \mathrm{p}>0,05\right)$, psikolojik dayanılkllık $\left(\mathrm{F}_{(3,402)}=0,832 ; \mathrm{p}>0,05\right)$, umut $\left(\mathrm{F}_{(3,402)}=0,080\right.$; $\mathrm{p}>0,05)$, öz yeterlilik $\left(\mathrm{F}_{(3,402)}=1,657 ; \mathrm{p}>0,05\right)$ ve psikolojik sermaye $\left(\mathrm{F}_{(3,402)}=0,142 ; \mathrm{p}>0,05\right)$ düzeyleri anlamlı bir değişiklik göstermemektedir.

\section{ilişki Testleri}

Araştırmaya katılan otel çalışanlarının psikolojik sermaye düzeyleri ile alt boyutları arasındaki ilişkilerin belirlenmesi amacıyla Pearson korelasyon katsayısı hesaplanmış, sonuçlar Tablo 9'da gösterilmiştir. 
Tablo 9. Otel Çalışanlarının Psikolojik Sermaye Düzeyleri Ile Alt Boyutları Arasında Hesaplanan Pearson Korelasyon Katsayısı Sonuçları

\begin{tabular}{|c|c|c|c|c|c|c|}
\hline Ölçek alt boyutları & Değerler & İyimserlik & Psikolojik dayanıklılık & Umut & Öz yeterlilik & Psikolojik sermaye \\
\hline \multirow[t]{3}{*}{ İyimserlik } & $\mathrm{r}$ & 1 &, $481 * *$ &, $531 * *$ &, $456^{* *}$ &, $731 * *$ \\
\hline & $\mathrm{p}$ & &, 000 &, 000 &, 000 & 000 \\
\hline & $\mathrm{N}$ & 403 & 403 & 403 & 403 & 403 \\
\hline \multirow[t]{3}{*}{ Psikolojik dayanıklılık } & $\mathrm{r}$ &, $481 * *$ & 1 &, $572 * *$ &, $545 * *$ &, $801 * *$ \\
\hline & $\mathrm{p}$ &, 000 & &, 000 &, 000 &, 000 \\
\hline & $\mathrm{N}$ & 403 & 403 & 403 & 403 & 403 \\
\hline \multirow[t]{3}{*}{ Umut } & $\mathrm{r}$ &, $531 * *$ &, $572 * *$ & 1 &, $649 * *$ &, $859 * *$ \\
\hline & $\mathrm{p}$ &, 000 &, 000 & &, 000 &, 000 \\
\hline & $\mathrm{N}$ & 403 & 403 & 403 & 403 & 403 \\
\hline \multirow[t]{3}{*}{ Öz yeterlilik } & $\mathrm{r}$ &, $456^{* *}$ &, $545 * *$ &, $649 * *$ & 1 &, $835 * *$ \\
\hline & $\mathrm{p}$ &, 000 & 000 &, 000 & &, 000 \\
\hline & $\mathrm{N}$ & 403 & 403 & 403 & 403 & 403 \\
\hline \multirow[t]{3}{*}{ Psikolojik sermaye } & $\mathrm{r}$ &, $731 * *$ &, $801 * *$ &, $859 * *$ &, $835^{* *}$ & 1 \\
\hline & $\mathrm{p}$ & ,000 & ,000 & ,000 & ,000 & \\
\hline & $\mathrm{N}$ & 403 & 403 & 403 & 403 & 403 \\
\hline
\end{tabular}

Tablo 9'da görüldüğü gibi otel çalışanlarının psikolojik sermayeleri ile umut $(r=0,859 ; \mathrm{p}<0,01)$, öz yeterlilik $(r=0,835 ; \mathrm{p}<0,01)$, psikolojik dayanıklılık $(\mathrm{r}=0,801 ; \mathrm{p}<0,01)$ ve iyimserlik $(\mathrm{r}=0,731$; $\mathrm{p}<0,01)$ boyutları arasında pozitif yönde ve yüksek düzeyde ilişkiler bulunmaktadır. Çalışanların psikolojik sermaye alt boyutları arasında da pozitif yönde ve orta düzeyde ilişkiler olduğu tespit edilmiştir. En yüksek ilişkinin umut ile öz yeterlilik puanları arasında olduğu belirlenmiştir $(r=0,649 ; \mathrm{p}<0,01)$. Başka bir anlatımla çalışanların umutları artış gösterdikçe öz yeterlilik algıları da artış gösterme eğilimdedir. Alt boyutlar arasında en düşük ilişki de iyimserlik ve öz yeterlilik puanları arasında hesaplanmıştır $(r=0,465 ; p<0,01)$.

\section{Sonuç ve Tartışma}

Bu araştırma kapsamında Nevşehir ilindeki 4 ve 5 yıldızlı otel çalışanlarının örgütsel psikolojik sermaye düzeyleri ve çalışanların demografik özelliklerine göre psikolojik sermayelerinin anlamlı bir değişiklik gösterip göstermediği incelenmiştir. Bu doğrultuda 403 çalışanla yürütülen araştırma sonrasında konaklama sektöründe çalışan kişilerin psikolojik sermayelerinin hem alt boyutlarda hem de genel olarak yüksek olduğu sonucuna ulaşılmıştır.

Çalışanların demografik özelliklerine göre psikolojik sermaye düzeylerinin anlamlı bir farklılık gösterip göstermediği incelenmiştir. Otel çalışanlarının cinsiyetlerine göre iyimserlik, psikolojik dayanıklılık, umut ve psikolojik sermaye düzeylerinin anlamlı bir değişiklik göstermediği belirlenmiştir. Bununla beraber erkek çalışanların kadın çalışanlara göre öz yeterlilik algılarının daha yüksek düzeyde olduğu tespit edilmiştir.

Araştırmaya katılan otel çalışanlarının medeni durumlarına göre iyimserliklerinin anlamlı bir değişiklik göstermediği saptanmıştır. Bununla birlikte evli çalışanların psikolojik dayanıklılık, 
umut, öz yeterlilik ve psikolojik sermaye düzeylerinin bekâr çalışanlardan anlamlı bir şekilde daha yüksek düzeyde olduğu belirlenmiştir.

Otel çalışanlarının öğrenim durumlarına göre psikolojik sermaye düzeylerinin anlamlı bir değişiklik göstermediği; başka bir anlatımla ilköğretim, lise, ön lisans, lisans ve üstünde bir eğitime sahip çalışanların psikolojik sermaye düzeylerinin benzerlik gösterdiği tespit edilmiştir.

Konaklama sektöründe çalışan kişilerin kıdemlerine göre de psikolojik sermaye düzeylerinin anlamlı bir farklılık göstermediği belirlenmiştir. Diğer bir anlatımla 1 yıl ve altında kıdeme sahip, 2-4 yıl, 5-9 yıl, 10 yıl ve üzerinde kıdeme sahip çalışanların iyimserlik psikolojik dayanıklılık, umut, öz yeterlilik ve psikolojik sermaye düzeylerinin benzerlik gösterdiği tespit edilmiştir.

Otel çalışanlarının yaşlarına göre de iyimserlik, psikolojik dayanıklılık, umut, öz yeterlilik ve psikolojik sermaye düzeylerinin anlamlı bir farklılık göstermediği saptanmıştır. 20-24, 25-34, 35-44, 45 yaş ve üstündeki çalışanların psikolojik sermayelerinin benzerlik gösterdiği belirlenmiştir.

Araştırmaya katılan otel çalışanlarının psikolojik sermayeleri ile iyimserlik, psikolojik dayanıklılık, umut, öz yeterlilik puanları arasında pozitif yönde ve yüksek düzeyde ilişkiler olduğu tespit edilmiştir. Alt boyutlar arasında en yüksek ilişkinin umut ve öz yeterlilik puanları arasında, en düşük ilişkinin de iyimserlik ve öz yeterlilik puanları arasında hesaplanmıştır.

\section{Kaynakça}

Bandura, A. (1997). Self-Efficacy: The Exercise of Control. New York: W. H. Freeman and Company.

Büyüköztürk, Ş. (2008). Sosyal Bilimler İçin Veri Analizi El Kitabı-İstatistik, Araştırma Deseni SPSS Uygulamaları ve Yorum. Ankara: PegemA.

Büyüköztürk, Ş., Çakmak, E.K., Akgün, Ö.E., Karadeniz, Ş. ve Demirel, F., (2016). Bilimsel Araştırma Yöntemleri, 9944-919-28-4, Ankara: PegemA.

Frankel, J.R., Wallen, N.E. (2009). How to design and evaluate research in education. (7). New York: McGraw-Hill İnternational Edition.

Çetin, F. ve Basım, H. J. (2012). Örgütsel Psikolojik Sermaye: Bir Ölçek Uyarlama Çalışması, Amme İdaresi Dergisi, 45(1), 121-137.

Güler, B.K., (2009) Çalışma Yaşamında Davranış, Kocaeli: Umuttepe.

Gohel, K. (2012). Psychological capital as a determinant of Employee Satisfaction, International Referred Research Journal, 3(36), 34-37.

Jung, H. S., \& Yoon, H. H. (2015). The Impact of Employees' Positive Psychological Capital on Job Satisfaction and Organizational Citizenship Behaviors in the Hotel, International Journal of Contemporary Hospitality Management, 27(6), 1135-1156. 
Kalaycı, Ş., (2009). SPSS Uygulamalı Çok Değişkenli İstatistik Teknikleri, 975-909-114-3, Ankara: Asil.

Kaplan, M., ve Biçkes, D.M. (2013). Psikolojik Sermaye ile İş Tatmini Arasındaki İlişkinin Analizi: Otel İşletmelerinde Yapılan Bir Araştırma, Yönetim ve Ekonomi: Celal Bayar Üniversitesi İktisadi ve İdari Bilimler Fakültesi Dergisi, 20(2), 233-242.

Karatepe, O. M., \& Karadas, G. (2015). Do Psychological Capital and Work Engagement Foster Frontline Employees' Satisfaction? A Study in the Hotel Industry, International Journal of Contemporary Hospitality Management, 27(6), 1254-1278.

Luthans, F. (2002). The Need For Meaning of Positive Organizational Behavior, Journal of Organizational Behavior, 23(6), 695-706. DOI: 10.1002/job.165

Luthans, K. W., Jensen, S. M. (2005). The Linkage Between Psychological Capital and Commitment to Organizational Mission: A Study of Nurses, Journal of Nursing Administration, 35(6), 304-310.

Luthans, F., Avolio, B. J., Avey, J. B., Norman, S. M. (2007). Positive Psychological Capital: Measurement and Relationship with Performance and Satisfaction, Personnel psychology, 60(3), 541-572.

Luthans, F., Youssef, C. M. ve Avolio, B. J. (2007). Psychological Capital: Developing the Human Competitive Edge. New York: Oxford University Press.

Özkalp, E. (2009). Örgütsel Davranışta Yeni Bir Boyut: Pozitif (Olumlu) Örgütsel Davranış Yaklaşımı ve Konuları, 17. Ulusal Yönetim ve Organizasyon Kongresi Bildiriler Kitabı, 491-498.

Seligman, Martin \& Schulman, P. (1986). Explanatory Style As A Predictor of Productivity and Quitting Among Life Insurance Sales Agents, Journal of Personality and Social Psychology. 50(4), 832-838.

Snyder, C. R. (2000). Handbook of Hope. Theory, Measures, \& Applications. San Diego: Academic Press.

Stewart, M., Reid, G. ve Mangham, C. (1997), Fostering Children 'es Resilience, Journal of Pediatric Nursing, 12, 21-31.

Wood, R.E. ve Bandura, A. (1989). Impact of Conceptions of Ability on Selfregulatory Mechanisms and Complex Decision Making, Journal of Personality and Social Psychology. $56,407-415$.

Youssef, C. M., \& Luthans, F. (2007). Positive organizational behavior in the workplace: Theimpact of hope, optimism, and resilience, Journal of Management, 33, 774-800. 